DOI: 10.20472/IAC.2018.044.038

\title{
DOROTA PASIŃSKA
}

Instytut Ekonomiki Rolnictwa i Gospodarki Żywnościowej -Państwowy Instytut Badawczy (Institute of Agricultural and Food Economics - National Research Institute), Poland

\section{GOOSE MARKET FROM GLOBAL AND DOMESTIC PERSPECTIVE IN THE YEARS 2012-2017}

\begin{abstract}
:
The main objective of the article is to present changes in the Polish goose meat market in the years 2012-2017 in the context of changes in the global goose meat market. Poland is one of the largest producers and exporters of goose meat in the world. In the analysed period, the production and sale of goose meat in Poland was of seasonal change, which, most probably in the case of availability of goose meat in retail trade will change, since buyers' preferences are changing and the demand for niche types of poultry meat is growing. At the turn of $2016 / 2017$, Poland was affected by avian influenza which had a negative impact on the production of and trade in goose meat. In 2013, Poland was the fifth largest global producer of goose meat. The structure of the global export of goose meat and offal (total) is very concentrated. In the analysed period, its largest global exporter was Hungary with the share ranging from $34 \%$ to $47 \%$ while Poland was ranked second with the share ranging from $31 \%$ to $37 \%$.
\end{abstract}

\section{Keywords:}

goose market, international trade, goose production, Poland, world

JEL Classification: Q11, Q17, Q13 


\section{Introduction}

Geese were domesticated about 5000 years ago. In Egypt, they can be found carved in reliefs of tombs, which also included goose mummies. In ancient Greece, goose eggs were eaten. Homer wrote about white geese and Aristotle noted the value of roast geese. The Romans knew the fattened goose liver (Szuman 1964).

Geese can provide not only meat, down, feathers (Rosiński 2003), fats (Wężyk 1999), offal, eggs (Wężyk 2004) but they can also be an attraction on agritourism farms (Kasprzykowska and other 2017). Polish feathers and down enjoy great recognition and the main buyer of down derived from White Kołuda Goose is Japan (Herbut 2018). Interest in goose feathers and down has been increasing - they are used instead of synthetic fibres in pillows, duvets and winter sportswear. In many countries, goose fat enjoys a lot of interest because it contains large amount of unsaturated fatty acids. In some regions of France and Germany, it is sold in the faience packaging as a luxury product (Wężyk 1999).

In some countries, fatty goose liver, which is one of the ingredients of foie gras, is highly popular. France is the world's largest producer of fatty liver (Łuczak 2012). In Poland, the protection of animals prohibits the fattening of geese for fatty liver [Dz.U. of 1997 No. Act of 21 August 1997 on the 111, item 724, as amended]. The prohibition of fattening geese for fatty liver may contribute to lowering the financial efficiency of production (Marciniec Smędzik-Ambroży 2013).

Goose meat contains all exogenous aminoacids and goose fat is characterised by the large share of mono- and polysaturated acids and is digestible. What is more, goose meat is a source of vitamins ( $A, E$ and $B$ group) and mineral substances (i.e. sodium, potassium, magnesium, zinc, copper and sulfur) (Grochowska and other 2016).

Geese are highly capable of absorbing green fodder, "can feed on weeds and herbs harmful to other species, hence they can be used successfully for weeding out many cultivations, especially orchards, plantations of strawberry, sugar beet, maize and tree nurseries" (Wężyk 1999, p. 132).

The main objective of the paper is to present changes in the Polish goose meat market in the years 2012-2017, against a background of changes in the global goose meat market. The basic method used to achieve the objective of the paper was comparative analysis over time (relative increments and fixed-and variable-based dynamics indices) of export goose meat and offal in total, individual product groups, and analysis of the global and Polish commercial structure of the export of selected goose products as well as slaughter and population of geese according to the scale of rearing in Poland. The obtained study results are important for agricultural producers of geese, processors, wholesale trade, retail trade, gastronomy and the economic policy of the state. The study uses annual data from the years 2012-2017, coming from the Central Statistical Office, FAO and the Comtrade 
database. Deviations from the adopted time range were mainly due to the lack of access to data.

\section{Trends in the goose stock and production in the world and in Poland}

In 2012 and 2013, the largest producer of goose meat in the world was China (with the share in the global production of, respectively, 94.6\% and 94.8\%) and Poland was ranked fifth among the global largest producers with the share of $0.7 \%$ in the global production of goose meat (see figure 1). Egypt, Hungary and Taiwan occupied, respectively, the second, third and fourth position. In Europe, the largest producers of goose meat are Hungary and Poland, both of which have a centuries-old tradition in the production of goose meat and a significant part of their production is exported (Molnar 2016).

Figure 1: Share of major producers of goose in global goose production in 2012 and 2013 in $\%$.

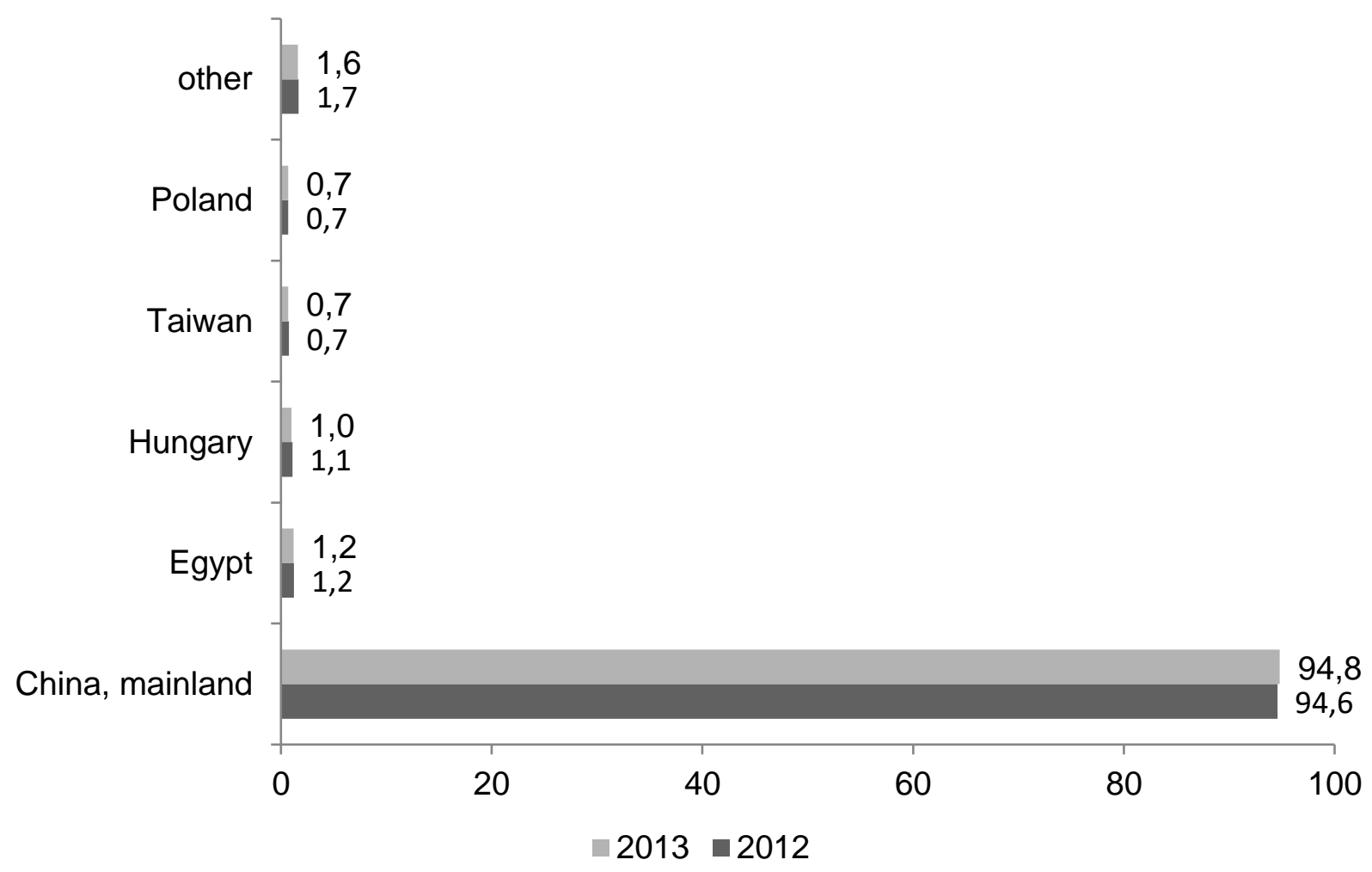

Source: own work based on FAO data: http://www.fao.org/faostat/en/\#data/QL, download date 22.08.2018.

Goose White Kołudzka has the largest share in domestic production of geese (about 95\%) (Kasprzykowska and other 2017). In 2017, compared to 2012, the slaughter of geese decreased from 37 thousand tonnes live weight to 36 thousand tonnes live weight (see figure 2), the reduction of slaughter was primarily determined by the occurrence of avian influenza in Poland in 2016 and 2017. In 2012-2017, the share of geese in the total 
domestic poultry slaughter ran from $1.1 \%$ to $1.9 \%$. At this time, chickens had the largest share in the structure of slaughter. In 2010, on average, there were 135 goose per farm in the country (GUS 2011).

The FAO data provide information on the stock of goose and guinea fowl together, therefore it is not possible to analyze it for geese only (FAO). In consequence, analysis of the global goose population has been abandoned.

Figure 2: Industrial slaughter of geese and other domestic poultry species in Poland (in thousands of tonnes in live weight)

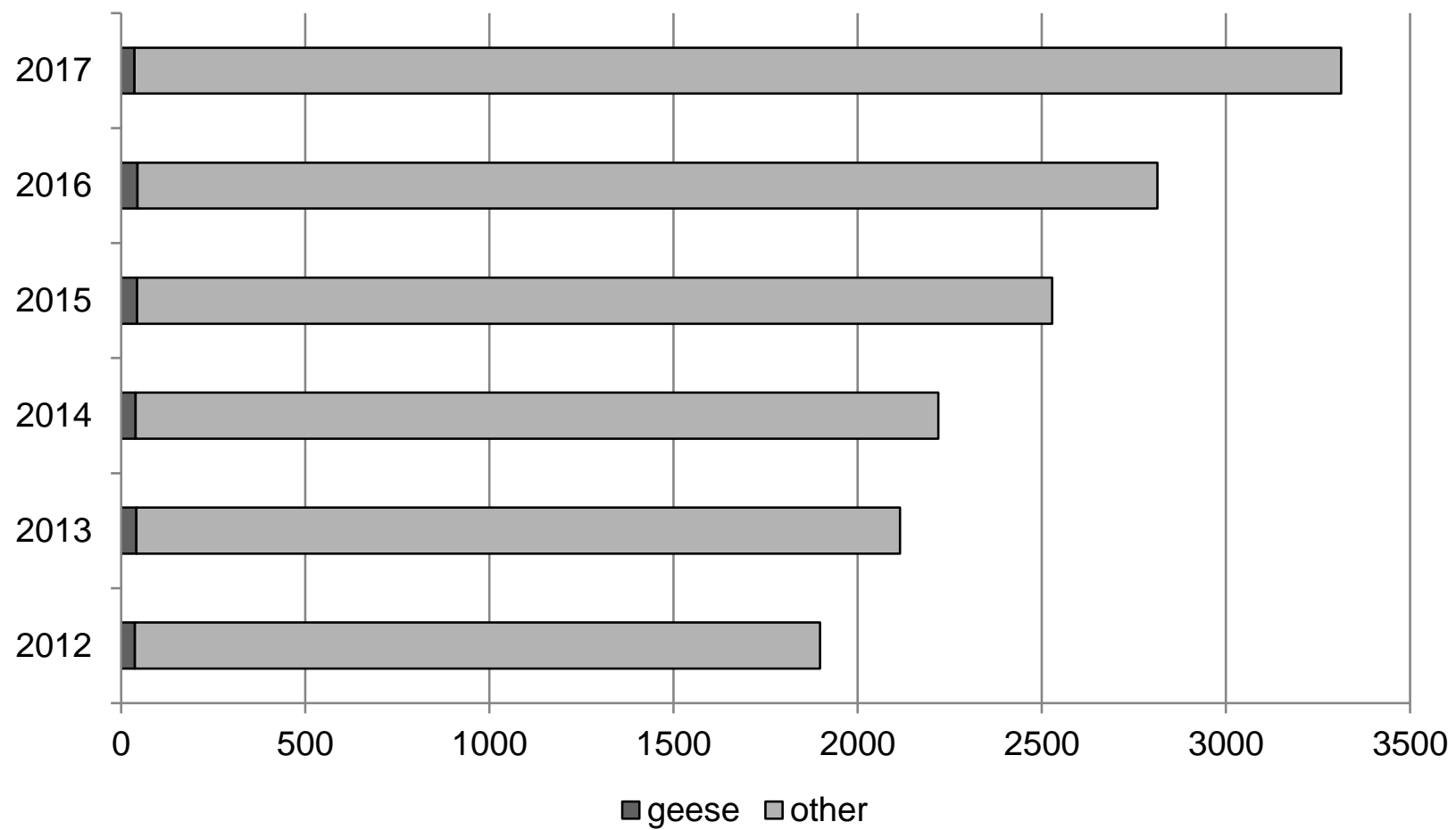

Source: own work based on the GUS (2013-2018)

In the period under review, there were significant changes in the goose population by provinces (see table 1) in Poland. Even though the largest number of geese is still kept in Wielkopolska Province (in 2012, the share in domestic goose population was $27,6 \%$ and in $2017-25,7 \%$ ), their stock in this province decreased by $27,1 \%$ (in 2017 , compared to 2012). In 2012, the greatest number of goose were kept in Kujawsko-Pomorskie $(11,0 \%$ of the population), Lubelskie $(8,2 \%)$, Lubuskie $(8,0 \%)$, Mazowieckie $(8,1 \%)$ and Podlaskie $(8,4 \%)$ Provinces, and in 2017 , in Warminśko-mazurskie $(16,1 \%)$, Łódzkie $(12,1 \%)$, Mazowieckie (10,7\%), Kujawsko-Pomorskie (8,4\%), Lubelskie (6,2\%). In 2017, compared to 2016 , the goose population in the Lubuskie Voivodeship decreased by $43,1 \%$, which was mainly the result of the occurrence of highly pathogenic avian influenza in Poland in 2016 and in 2017 in this region. In 2017 the smallest number of geese comes from Zachodniopomorskie, Opolskie, Śląskie, Dolnośląskie and Małopolskie Voivodeships. 
Table 1: Stock (in thousands of heads), changes in stock (in \%) and geographical structure of goose population (in \%) in Poland

\begin{tabular}{|c|c|c|c|c|c|c|c|c|c|c|c|c|c|c|}
\hline \multirow{3}{*}{ Specyfication } & \multicolumn{2}{|c|}{ Livestock } & \multicolumn{6}{|c|}{ Dynamics } & \multicolumn{6}{|c|}{ Share } \\
\hline & \multirow{2}{*}{2012} & \multirow{2}{*}{2017} & 2013 & 2014 & 2015 & 2016 & 2017 & \multirow{2}{*}{$\begin{array}{r}2017 \\
2012 \\
=100 \\
\end{array}$} & \multirow{2}{*}{2012} & \multirow{2}{*}{2013} & \multirow{2}{*}{2014} & \multirow{2}{*}{2015} & \multirow{2}{*}{2016} & \multirow{2}{*}{2017} \\
\hline & & & \multicolumn{5}{|c|}{ Previous year $=100$} & & & & & & & \\
\hline Poland & 1219 & 953 & 107,8 & 92,0 & 100,3 & 70,8 & 110,9 & 78,1 & 100,0 & 100,0 & 100,0 & 100,0 & 100,0 & 100,0 \\
\hline Voivodeship: & & & & & & & & & & & & & & \\
\hline Dolnośląskie & 23 & 6 & 106,0 & 22,2 & 257,1 & 47,5 & 88,3 & 25,4 & 1,9 & 1,8 & 0,4 & 1,1 & 0,8 & 0,6 \\
\hline $\begin{array}{l}\text { Kujawsko- } \\
\text { pomorskie }\end{array}$ & 135 & 80 & 95,7 & 67,3 & 88,7 & 136,9 & 75,7 & 59,2 & 11,0 & 9,8 & 7,2 & 6,3 & 12,3 & 8,4 \\
\hline Lubelskie & 100 & 59 & 108,2 & 66,8 & 137,6 & 101,6 & 58,4 & 58,9 & 8,2 & 8,2 & 6,0 & 8,2 & 11,8 & 6,2 \\
\hline Lubuskie & 97 & 15 & 97,4 & 72,2 & 23,7 & 162,8 & 56,9 & 15,4 & 8,0 & 7,2 & 5,7 & 1,3 & 3,1 & 1,6 \\
\hline Łódzkie & 88 & 115 & 130,9 & 172,1 & 137,8 & 38,0 & 111,2 & 131,2 & 7,2 & 8,8 & 16,4 & 22,5 & 12,1 & 12,1 \\
\hline Małopolskie & 31 & 8 & 95,4 & 45,8 & 156,7 & 73,2 & 51,3 & 25,8 & 2,6 & 2,3 & 1,1 & 1,8 & 1,8 & 0,8 \\
\hline Mazowieckie & 99 & 102 & 117,5 & 76,2 & 66,8 & 189,4 & 90,9 & 102,9 & 8,1 & 8,8 & 7,3 & 4,9 & 13,0 & 10,7 \\
\hline Opolskie & 9 & 4 & 99,0 & 45,1 & 65,2 & 69,3 & 215,0 & 43,4 & 0,7 & 0,7 & 0,3 & 0,2 & 0,2 & 0,4 \\
\hline Podkarpackie & 8 & 14 & 129,6 & 196,5 & 92,0 & 94,9 & 83,2 & 185,0 & 0,6 & 0,7 & 1,6 & 1,4 & 1,9 & 1,5 \\
\hline Podlaskie & 102 & 99 & 120,7 & 101,5 & 85,8 & 95,7 & 96,3 & 96,9 & 8,4 & 9,4 & 10,4 & 8,9 & 12,0 & 10,4 \\
\hline Pomorskie & 36 & 28 & 96,0 & 51,4 & 286,7 & 24,5 & 221,5 & 76,6 & 3,0 & 2,6 & 1,5 & 4,2 & 1,4 & 2,9 \\
\hline Śląskie & 16 & 6 & 95,3 & 30,1 & 143,8 & 89,5 & 100,2 & 37,0 & 1,3 & 1,2 & 0,4 & 0,6 & 0,7 & 0,6 \\
\hline Świętokrzyskie & 82 & 17 & 98,9 & 54,3 & 102,4 & 34,5 & 108,1 & 20,5 & 6,7 & 6,1 & 3,6 & 3,7 & 1,8 & 1,8 \\
\hline $\begin{array}{l}\text { Warmińsko- } \\
\text { mazurskie }\end{array}$ & 52 & 153 & 122,6 & 274,1 & 61,9 & 63,7 & 221,2 & 293,2 & 4,3 & 4,9 & 14,5 & 9,0 & 8,1 & 16,1 \\
\hline Wielkopolskie & 336 & 245 & 105,1 & 80,2 & 109,5 & 52,2 & 151,2 & 72,9 & 27,6 & 26,9 & 23,4 & 25,6 & 18,9 & 25,7 \\
\hline $\begin{array}{l}\text { Zachodniopomorski } \\
\mathrm{e}\end{array}$ & 5 & 3 & 132,4 & 33,8 & 162,2 & 49,8 & 146,2 & 52,8 & 0,4 & 0,5 & 0,2 & 0,3 & 0,2 & 0,3 \\
\hline
\end{tabular}

Source: own work based on the GUS (2013-2018)

The production of geese in Poland was concentrated; in 2010, $76.9 \%$ of the goose population was kept in flocks of 3000 thousand and more head by only $1.2 \%$ of farms rearing; $6.4 \%$ of the stock were in flocks of 1 to 99 head, kept by $97 \%$ of the farms goose (see figure 3). In 2010, the number of farms engaged in rearing geese was 37.8 thousand (GUS 2011). 
Figure 3: Structure of goose stock according to the scale of farming in 2010 (in \%) (from 1 to 3000 heads and more) in Poland

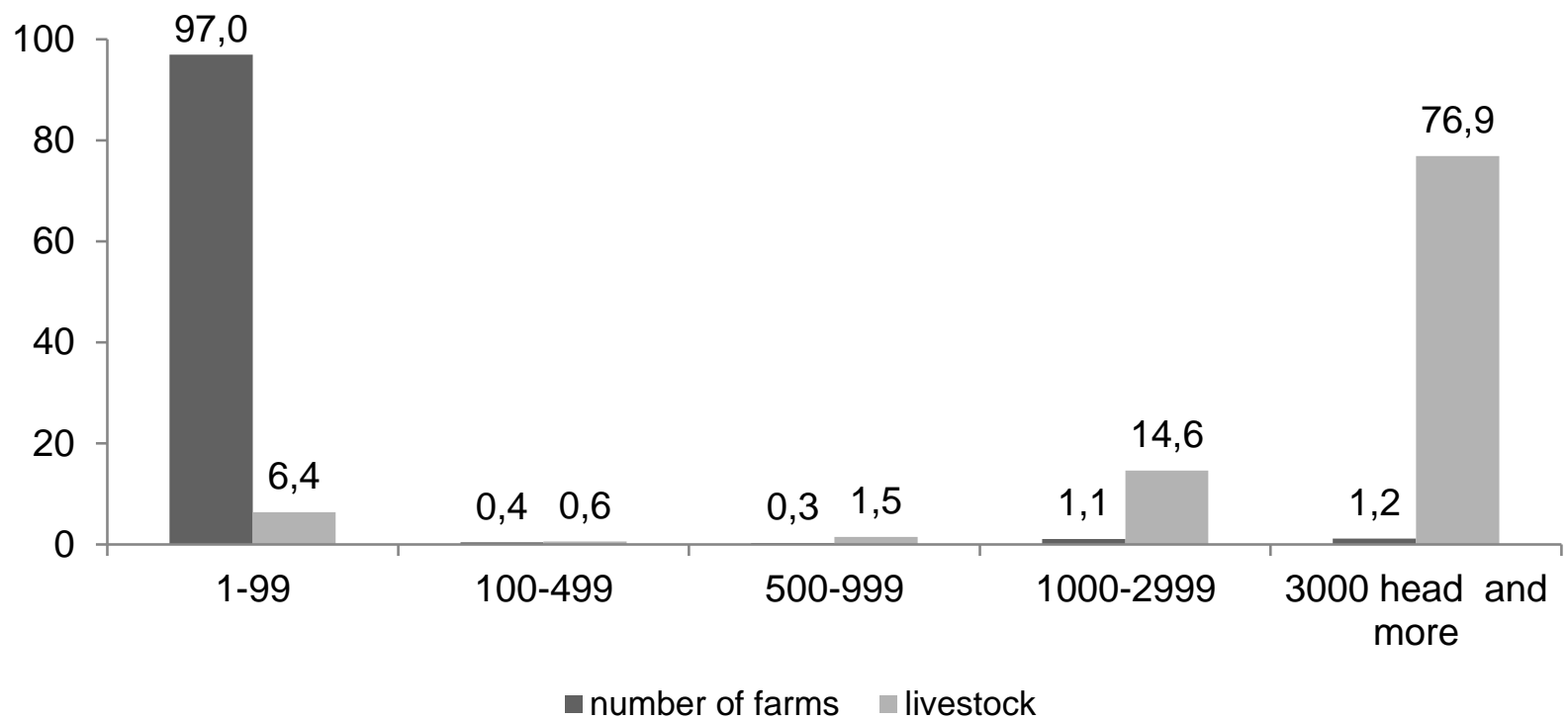

Source: own work based on the GUS: (GUS 2011)

\section{Global and Polish export of goose meat and offal}

In 2017, when compared to 2012, the global export of goose meat and offal decreased by 13\% to USD 275 million dollars, which resulted from the reduced export of frozen carcasses by $6 \%$, fresh or chilled fatty livers by $57 \%$, other fresh or chilled meat by $18 \%$, other frozen meat by $17 \%$ (see figure 4 and table 2). At that time, the export of this product from Poland decreased by 3\% to USD 102 million. The polish export of all product groups decreased, except for other frozen meat and offal.

Figure 4: Global and Polish export of goose meat and offal in million USD

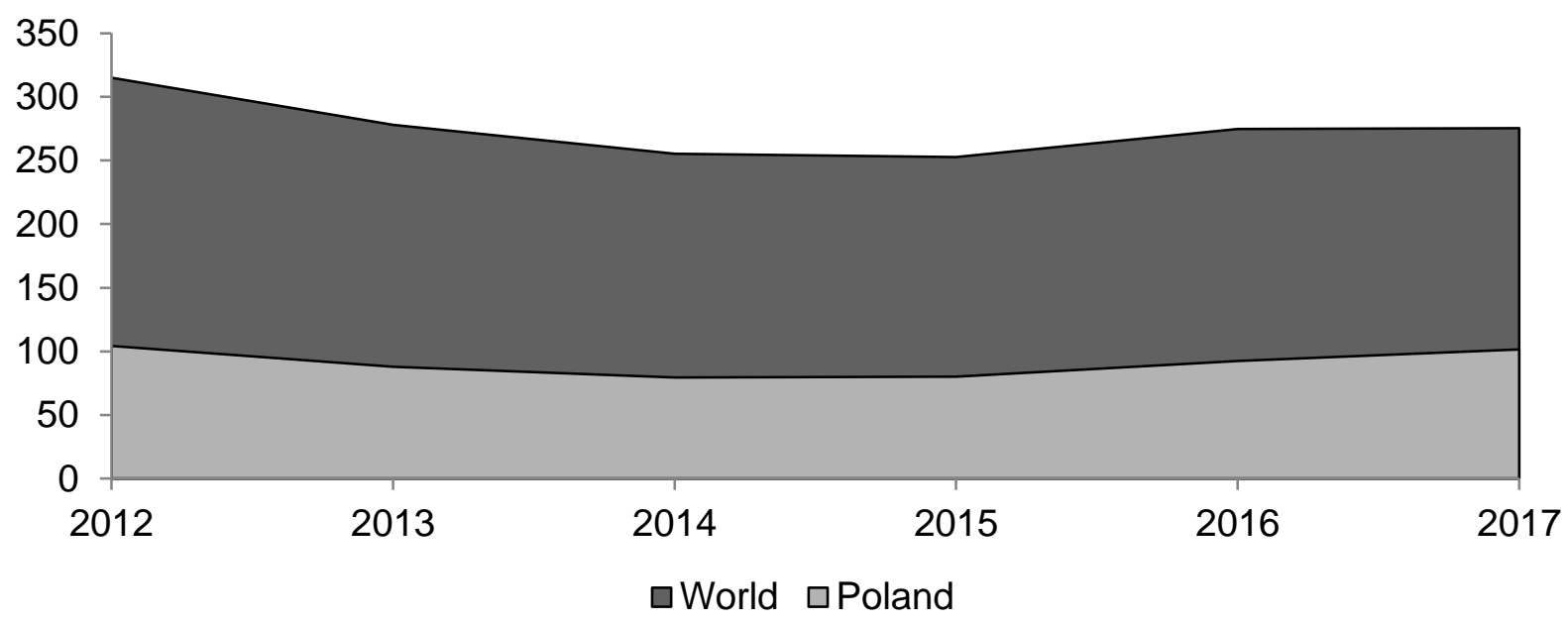

Source: own study based on: https://comtrade.un.org/data/ (download date: 22/08/2018). 
Table 2: Changes in the global and Polish export of goose meat and offal (in \%)

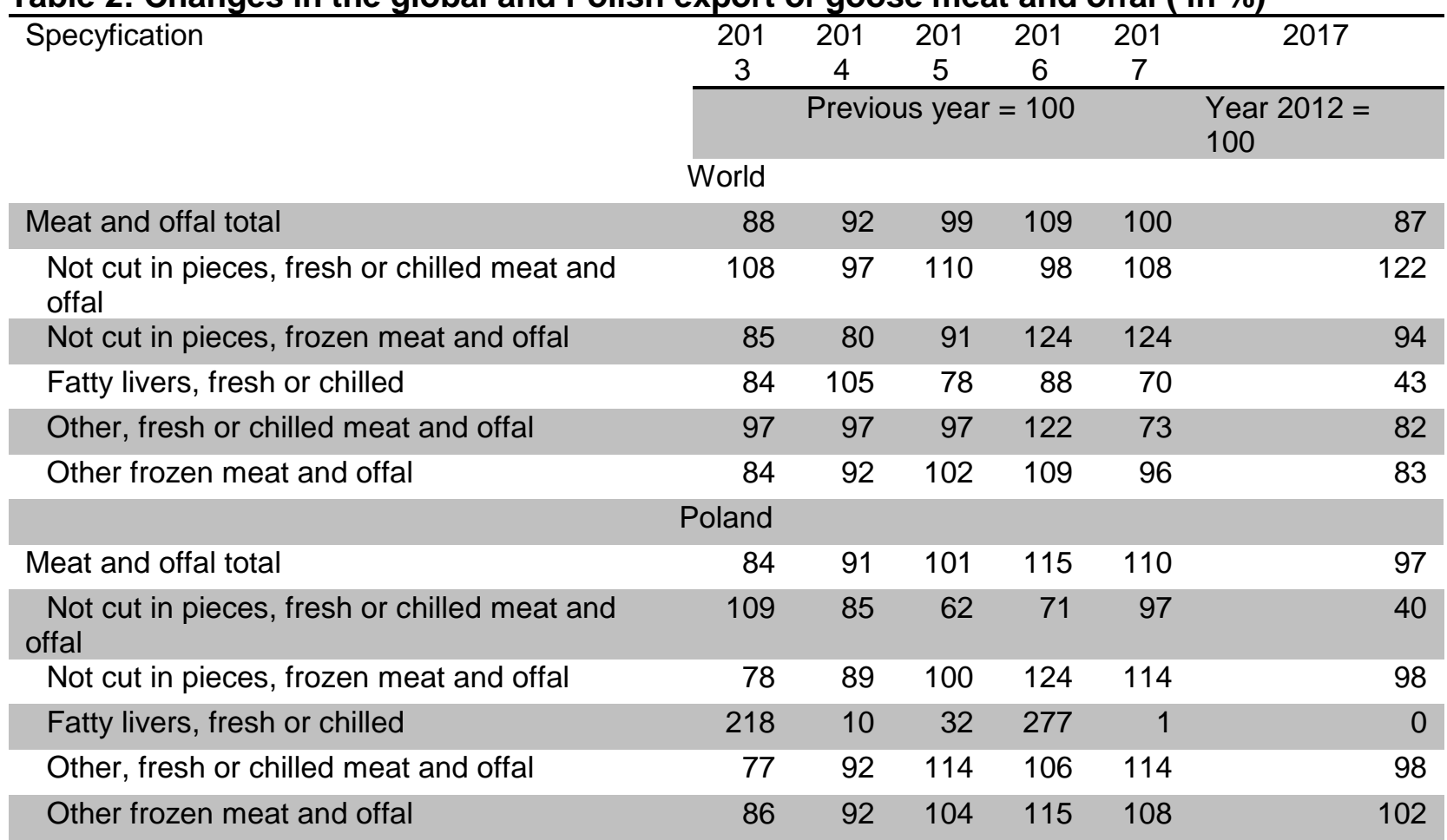

Source: own study based on: https://comtrade.un.org/data/ (download date: 22/08/2018).

In the analysed period, the structure of the global export of goose meat and offal has changed (see figure 5). Mainly frozen meat was exported. The largest share was that of other frozen meat and offal (from 50\% to 53\%). Significant shares in the export were also those of frozen carcasses (16\% to $22 \%$ ), uncut fresh or chilled cuts (14\% to $20 \%$ ). Fresh or chilled livers and other fresh or chilled meat had small shares ranging from 4 to $8 \%$ and from 5 to $6 \%$, respectively.

Figure 5: Structure of global goose meat and offal export in\%

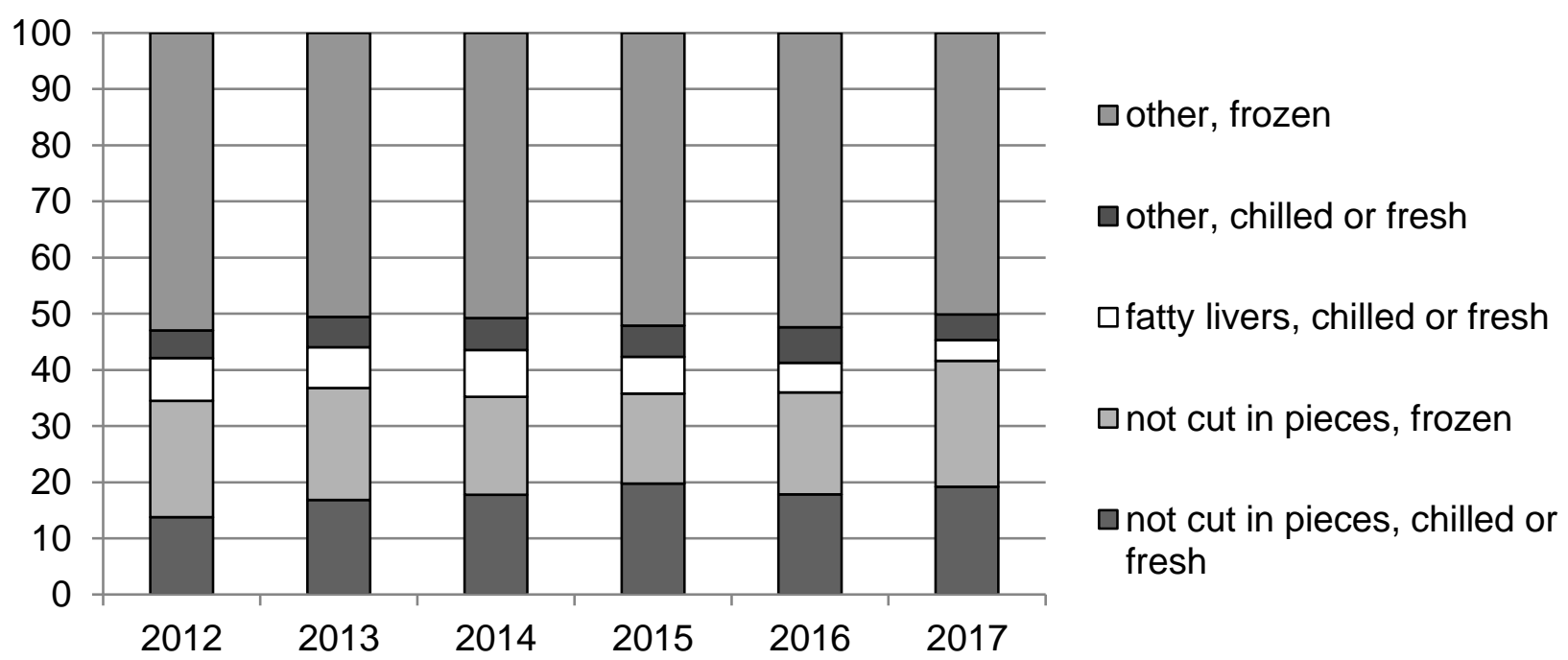

Source: own study based on: https://comtrade.un.org/data/ (download date: 22/08/2018). 
In the years 2012-2017, the share of Poland in the global export of goose meat ranged from $31 \%$ to $37 \%$, Poland was ranked second in the list of the largest global producers while the first position was occupied by Hungary, whose share in the global export ranged from $34 \%$ to $47 \%$. Poland and Hungary are competing between themselves for the stable market of goose meat i.e. Germany (Molnar 2016).

In the analysed period, the share of the individual product groups exported from Poland in the global export of these groups was diversified (see table 3). In the years 2012-2017, we could observe the high share of the Polish export of frozen goose carcasses (with or without offal) in the global export (from $45 \%$ to $55 \%$ ). The share of the Polish export of fresh or chilled fatty livers in the global export of this product was marginal and ranged from $0 \%$ to $1 \%$. In 2017, when compared to 2012, the share of uncut fresh or chilled goose meat exported from Poland to the global export of this group decreased by 7 percentage points to $4 \%$, the share of other fresh or chilled goose meat and offal increased by 10 percentage points to $57 \%$ and of other frozen products by 8 percentage points to $44 \%$.

Table 3: The share of Polish export of individual goose product groups in the global export of these groups in \%

\begin{tabular}{lrrrrrr}
\hline Specyfication & 2012 & 2013 & 2014 & 2015 & 2016 & 2017 \\
\hline Not cut in pieces, fresh or chilled meat and offal & 11 & 11 & 10 & 6 & 4 & 4 \\
Not cut in pieces, frozen meat and offal & 49 & 45 & 50 & 55 & 55 & 51 \\
Fatty livers, fresh or chilled & 0 & 1 & 0 & 0 & 0 & 0 \\
Other, fresh or chilled meat and offal & 47 & 37 & 35 & 42 & 36 & 57 \\
Other frozen meat and offal & 36 & 37 & 37 & 37 & 39 & 44 \\
Meat and offal total & 33 & 32 & 31 & 32 & 34 & 37 \\
\hline
\end{tabular}

Source: own work based on the: https://comtrade.un.org/data/ (download date 22.08.2018)

In the analysed period, the structure of the Polish export of goose meat and offal used to change, although it was dominated by other frozen cuts of goose meat and offal (their share ranged from $57.6 \%$ to $61.3 \%$ ) (see figure 6 ). The second position in the structure was occupied by frozen carcasses (with the share from $27.8 \%$ to $30.9 \%$ ). Much smaller shares in the export were those of fresh or chilled carcasses (with offal or without offal) (from 1.9 to $6.1 \%$ ), other chilled or fresh meat and offal (from $6.4 \%$ to $7.4 \%$ ) and fresh or chilled fatty livers $(0 \%$ to $0.2 \%)$. 
Figure 6. Structure of Polish export of goose meat and offal in \%

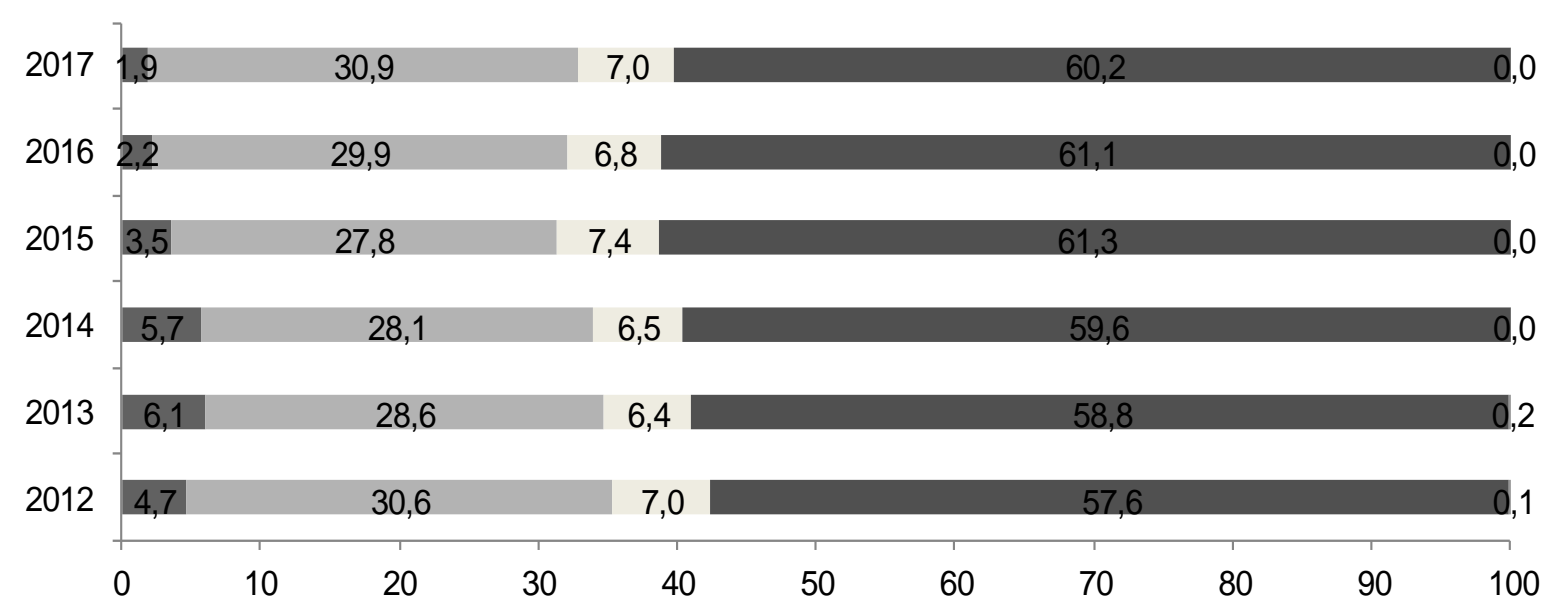

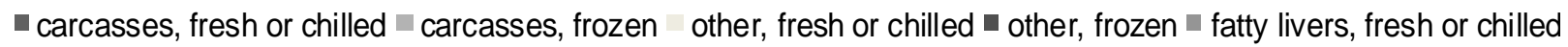

Source: own work based on the: https://comtrade.un.org/data/ (download date 22.08.2018)

\section{Conclusions}

Poland is expected to continue to be one of the main global exporters of goose meat and one of the largest producers in Europe, provided that there are no serious market disturbances e.g. avian influenza. For producers of this poultry species, the prevention of the negative effects of avian flu is often associated with additional costs and, consequently, lower profitability of production. Geese must be able to use the runs. The producer should consider additional costs associated with a fence, especially when there are many foxes around, or with a protection against contact with wild birds (which is especially important during periods of avian influenza). In fact, wild birds are carriers of avian influenza (Lis 2005). Poland is less competitive when compared to many countries due to the prohibition of rearing geese for fatty livers. The geographical structure of the Polish export is poorly diversified. Since a significant part of the Polish production is exported, the situation of the sector may also be affected by exchange rates. Ant opportunity for the Polish export may be to improve the knowledge of goose meat in countries (especially those with higher disposable income per capita) consuming even less goose meat than in Poland or not consuming it almost at all. In some Asian countries, it is possible to sell the elements of goose which are less popular in Europe. Polish goose meat, down and feathers can be products associated with Poland in many countries of the world.

In the analysed period, the production of goose meat was characterised by considerable seasonality, mainly related to the demand of its main buyer i.e. Germany. It is estimated that the growing demand for less known types of poultry meat in Poland, with the buyer preferring chilled (not frozen) meat, will make the sale of geese stop being so seasonal in Poland. The increased production of live geese in Poland may be supported by the increased demand for goose down and feathers. 


\section{References}

GUS (2013-2018). Zwierzęta gospodarkie w 2012 r.,...., 2017.. Warszawa: Główny Urząd Statystyczny.

Grochowska, K., Kołodziejczyk, D., Socha, S. (2016). Znaczenie mięsa w żywieniu człowieka i preferencje konsumentów związane z jego spożyciem na przestrzeni ostatnich 30 lat, Wiadomości Zootechniczne, R. LIV, 4, pp. 34-45.

GUS, (2011). Powszechny Spis Rolny 2010. Zwierzęta gospodarskie i wybrane elementy metod produkcji zwierzęcej. Warszawa.

Herbut, E. (2018), Puch od gęsi Białej Kołudzkiej, Wiadomości Zootechniczne. R. LVI, 1, pp. 178-183.

Kasprzykowska, A.; Riedel, J.; Michalczuk, M.; Damaziak K., Kalińska A. (2017). Gęś biłgorajska w gospodarstwie agroturystycznym cz. 1. Polskie Drobiarstwo, no. 5, pp. 8-9.

Lis, H. (2005). Grypa ptaków - występowanie, zwalczanie i zapobieganie. Życie Weterynaryjne, 80(11), pp. 688-689

Łuczak, W.; Kubizna J. (2012). Tajemnice gęsiej wątroby - luksus czy dekadencja. Polskie Drobiarstwo. no 10., pp. 20-23.

Marciniec, J., Smędzik-Ambroży, K., Rynek gęsi jako niszowy na rynku drobiu [in] A. Czyżewski, K. SmędzikAmbroży (red.). Dylematy wspólnej polityki rolnej w świetle doświadczeń lat 2007-2013. Wydawnictwo Kujawsko-Pomorskiej Szkoły Wyższej w Bydgoszczy, Bruksela-Bydgoszcz-Poznań 2013, pp. 167178.

Molnár, S. (2016). Evaluation of the Hungarian and Polish goose meat production. Rocznki Naukowe Stowarzyszenia Ekonomistów Rolnictwa i Agrobiznesu, tom XVIII, zeszyt 3, pp. 255-261.

Poland Animal Protection Act of August 21. 1997 (OJ No 111, Item 724 as amended).

Szuman, J. Typy użytkowe i rasy [w] E. Potemkowska (red.). Drobiarstwo. Państwowe Wydawnictwo Rolnicze i Leśne, Warszawa 1964, pp. 219-220.

Wężyk S., Chów gęsi [in] Świerczewska, E.; Wężyk S.; Horbańczuk J., Chów drobiu. Owh Oficyna Wydawnicza „Hoża” Spółdzielnia Pracy, Warszawa 1999, pp. 132-164.

Wężyk, S. (2004). Gęś - ptak ciągle zapomniany mało znany i niedoceniany, Polskie Drobiarstwo, no. 4, pp. 7-11 